\title{
A Comparison of Elizabeth and Mary in Pride and Prejudice
}

\author{
Changle Fu, Feifei Pei, Xiaolin Huang \\ Air Force Logistics College, Xuzhou, China \\ Email: sisi612@163.com
}

Received 23 July 2014; revised 25 August 2014; accepted 22 October 2014

Copyright (C) 2014 by authors and Scientific Research Publishing Inc.

This work is licensed under the Creative Commons Attribution International License (CC BY).

http://creativecommons.org/licenses/by/4.0/

c) (i) Open Access

\begin{abstract}
In Pride and Prejudice, Elizabeth is the more glamorous girl and thus has attracted more attention. Is she a perfect girl? What's her characteristic? With the questions, the article will first probe into the characteristic of Elizabeth and her sister Mary, and then compare the two girls. First, I analyze Elizabeth's character. Although she is a sensible, brave, beautiful and well-educated girl, sometimes she is reasonless. Second, I analyze Mary's mixed character, Mary's pedantry makes her indifferent even to her family members. Last, I compare Elizabeth and Mary. Both Elizabeth and Mary are occasionally reasonless, and both read widely, but they are quite different in their response to the same events. Mary is the representative of those who hold reason superior to feeling; unlike Mary, who is not a slave to social restriction, Elizabeth holds feeling superior to reason.
\end{abstract}

\section{Keywords}

Elizabeth, Mary, Character, Comparison

\section{Introduction}

Pride and Prejudice is Jane Austen's earliest work, and is usually considered to be the most popular of Austen's novels. The protagonist, Elizabeth, is not so perfect a woman. She is not sane enough in many things. She did her work with esteem and independence. She did her work with extremely care, which was described as "carved on two inches of ivory" (Wilson, 1985). In the novel there is another girl Mary, one of Elizabeth's sisters. They are much alike in many aspects, but also quite different in their response to the same events. This article will analyze the character of Elizabeth and Mary respectively, and then compare the two girls to see Mary's significance in the novel and the author's purpose to create such a character.

\section{Elizabeth's Character}

Elizabeth Bennet, the protagonist of Pride and Prejudice, is considered a fairly well-rounded character; she is a 
sensible, brave, beautiful and well-educated woman. Even such an excellent woman sometimes is reasonless.

First of all, her view for life is too ideal. Independent spirit can be named as the driving force in Elizabeth's refusal to marry her foolish and pompous cousin Collins. Although she was quite aware of the need to marry in order to avoid economic hardship later in life, Elizabeth was determined to marry only when she feels affection for the man, but she had none for her unfortunate cousin. When she learned that her best friend Charlotte's decision to marry Mr. Collins, she showed her surprise. “... Between Elizabeth and Charlotte there was a restraint which kept them mutually silent on the subject; and Elizabeth felt persuaded that no real confidence could ever subsist between them again...” (Austen, 1996).

While Elizabeth will not marry without affection, her friend's condition is quite different because of slimmer possibilities. Charlotte is 27 years old and has few marriage prospects. She is from a large family with several children and she herself has little education, money or beauty. But the situation of Elizabeth is different: she has the advantage of beauty, a sharp mind and other qualities that enable her to find the right person. So Elizabeth is reasonless to evaluate her friend's choice with her norm.

Elizabeth is also very kind a woman; she always fights for the underdog. Sometimes she sympathizes with the underdog blindly, whether real or perceived. In some event, her view is so superficial and cannot see the fact clearly.

Elizabeth's first impression on Darcy was quite bad, and her first impression on Wickham was the opposite. In her mind Darcy destroyed Wickham's future, and she never doubted Wickham's words. When they first talked about Darcy, Wickham was quite interested in how long Mr. Darcy had being stayed there and when he would leave, he asked such questions twice. The first time he began the subject himself, “... asked in a hesitating manner how long Mr. Darcy had been staying there” (Austen, 1996). And the second time was a few minute later, "whether he is likely to be in this country much longer" (Austen, 1996). His hesitating manner and the concern of Mr. Darcy's whereabouts show that he was with a guilty conscience. When Elizabeth said, "I hope your plans to favor of the-shire will not be affected by his being in the neighborhood” (Austen, 1996). He said:

Oh! No-it is not for me to be driven away by Mr. Darcy. If he wishes to avoid seeing me, he must go. We are not on friendly terms, and it always gives me pain to meet him, but I have no reason for avoiding him but what I might proclaim to all the world; a sense of very great ill usage, and most painful regrets at his being what he is (Austen, 1996).

In fact, he did not dare to face Mr. Darcy, and he didn’t appear in the ball later. Elizabeth conceals such important information about Wackham, she misjudges two men's characters and listened to what is said rather than used her analytical skills to root out the truth, so she blindly sympathizes with the underdog.

\section{Mary's Mixed Character}

Mary Bennet, the third daughter of the family, is a learned and confident girl, she lives in her own world. She is of a mixed character.

She does not have the advantage of beauty like her other sisters, so she reads widely in order to acquire the profound knowledge. We can see this easily from the novel that her only interest is reading. She wants to appeal other's attention through her scholarship. But unfortunately, she never seems to gain her ends. When Mrs. Bennet, Charlotte, Elizabeth and the children were talking about Darcy's pride, she gave her ideas, "Pride... is a very common failing I believe. By all that I have ever read, I am convinced that it is very common indeed, that human nature is particularly prone to it, and there are very few" (Austen, 1996). Of course, her words are quite reasonable, but it is not fit for such situation. They were having a chat in the free time, but Mary, like a scholar, told them that almost everyone will pride and the difference between pride and vanity. She did not realize that they are chatting not studying, so no one gave her the responses and instead, she was found both funny and annoying.

Mary's pedantry makes her indifferent even to her family members. When their youngest sister Lydia eloped with Wackham, everyone was anxious except Kitty and Mary:

In the dining-room they were soon joined by Mary and Kitty, who had been too busily engaged in their separate apartments to make their appearance before. One came from her books, and the other from her toilette. The face of both, however, were tolerably calm; and no changes was visible in either, except that the loss of her favorite sister, or the anger which she had herself incurred in the business, had given some- 
thing more of fretfulness than usual to the accents of Kitty. As for Mary, she was mistress enough of herself to whisper to Elizabeth with a countenance of grave reflection soon after they were seated at table (Austen, 1996).

This shows that she is rather selfish. When misfortune happens, she cares more about her reputation, and her unkind words are the snow plus frost.

\section{The Comparison between Elizabeth and Mary}

Elizabeth and Mary have many similar characteristics, for example, both have read widely and both are somehow not keen observers, but they are quite different. Elizabeth is flexible: she knows the principles written on the book, but she pays more attention to the people and things in the true life, so she is liked by many people; because of too much reading, Mary's sense seems artificial. In order to show her knowledge, she always says the wrong words at the wrong time, so nobody likes her. When Jane wrote to Elizabeth from Nether field, saying that she found herself unwell, Elizabeth decided to go to see her sister immediately, even though there was no right transport for her and the road was miry because of the rain. Everyone told her the aftereffect of her appearance at Nether field on foot, and she, although knew it quite well that she would be thought of underbred in other people's eyes, did not mind. In her mind, her sister was much more important than the etiquette. Mary is inflexible, she told Elizabeth, "I admire the activity of your benevolence", ... "but every impulse of feeling should be guided by reason; and, in my opinion, exertion should always be in proportion to what is required" (Austen, 1996). Her sentences tell us she is the typical production of traditional thoughts with adultly way of speaking; her mind indicates that she is controlled by the social principle.

\section{Conclusion}

Elizabeth has a lot of shortcomings, so Austen created Mary, a foolish character, to be a foil to Elizabeth. Mary is sensible, but her sense differs from that of Elizabeth in penetration and expression, she reads great books and makes extracts. While she does read and reflect a great deal, she does not acquire wisdom. As far as expression is concerned, Mary's sense never matches what the situation requires. This is one of the differences between Elizabeth and Mary.

Unlike Mary, Elizabeth is not a slave to social restrictions; she regards the well-being of her sister more important than her temporary ignorance of social etiquette. That's why she arrived at Mr. Bingley's house on foot with the skirt full of slurry. Mary holds the reason superior to feeling. This is another difference between them.

Mary's character does not receive Austen's approval; she is the representative of the fraction people who hold reason superior to feeling. Although Elizabeth's kindness and high self-belief sometimes lead to the wrong judgments, but she holds feeling superior to reason; this is her real characteristic.

\section{References}

Austen, J. (1996). Pride and Prejudice. Beijing: The Commercial Press.

Wilson, R. (1985). Macmillan Master Guides: Pride and Prejudice by Jane Austen. London: Macmillan Education Ltd. 
Scientific Research Publishing (SCIRP) is one of the largest Open Access journal publishers. It is currently publishing more than 200 open access, online, peer-reviewed journals covering a wide range of academic disciplines. SCIRP serves the worldwide academic communities and contributes to the progress and application of science with its publication.

Other selected journals from SCIRP are listed as below. Submit your manuscript to us via either submit@scirp.org or Online Submission Portal.
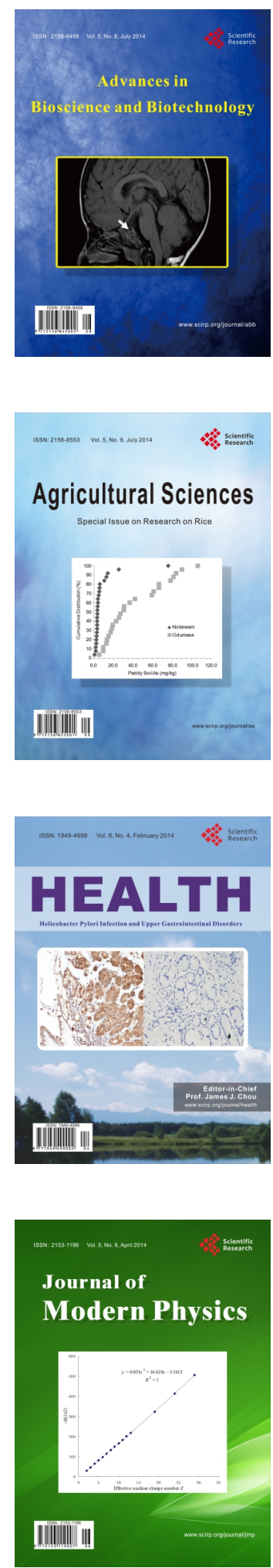
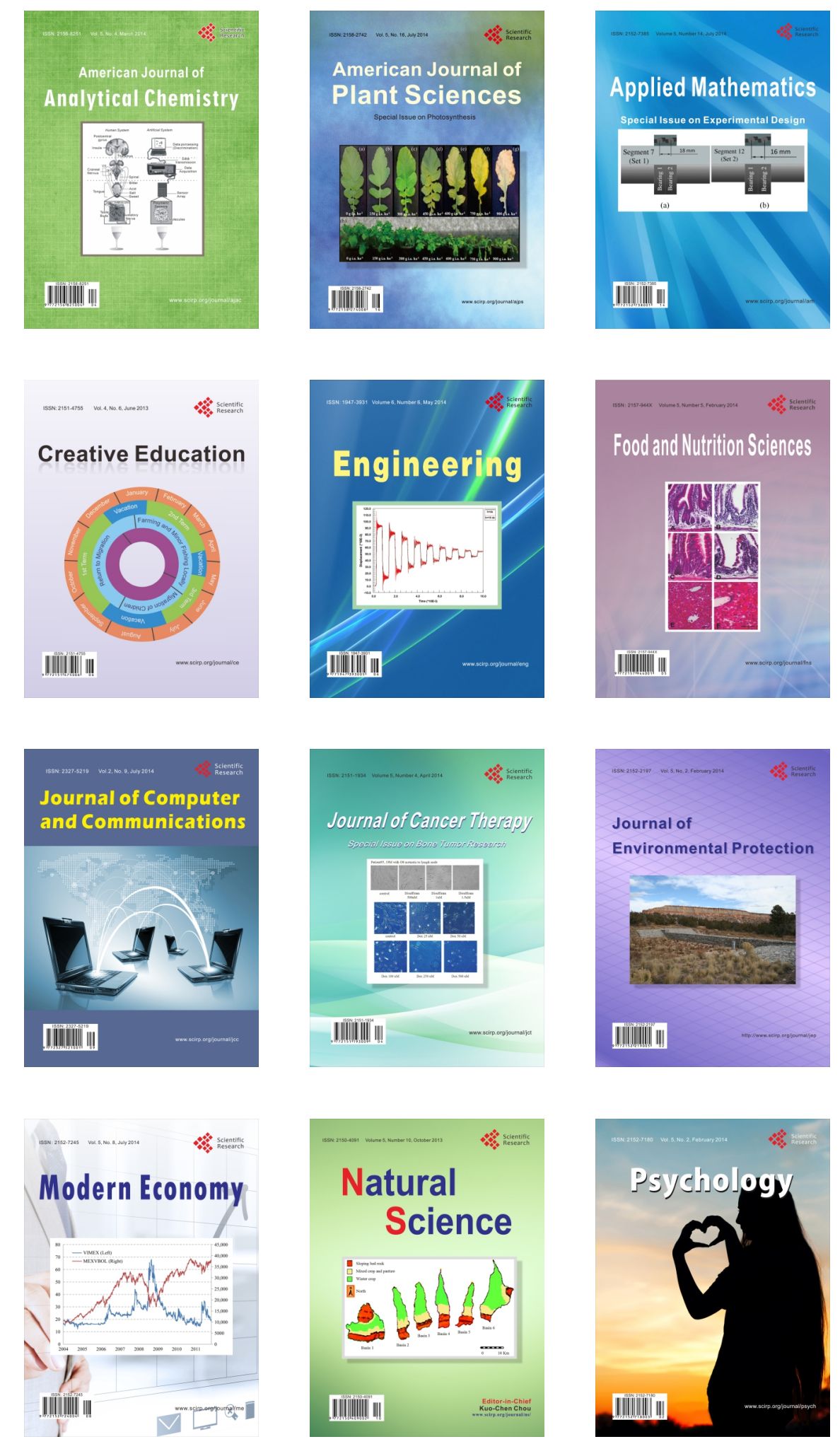